\title{
RADIOCARBON DATING AND AUTHENTICATION OF ETHNOGRAPHIC OBJECTS
}

\author{
P Richardin ${ }^{1}$ N Gandolfo \\ Centre de Recherche et de Restauration des Musées de France (C2RMF), Palais du Louvre, Porte des Lions, 14 quai François \\ Mitterrand, 75001 Paris, France.
}

\begin{abstract}
This article describes the contribution of the radiocarbon dating method to the authentication of ethnographic objects on some significant examples coming from the collections of the Quai Branly Museum (Paris, France) and the Museum of African Arts (Marseilles, France).The first object is a bludgeon of hard wood from the Tupinambá ethnic group and thought to be brought from Brazil by Andre Thévet, cosmographer of King Francis I. This object supposedly dates to the 16th century. Another example concerns a series of architectural columns, brought from Peru in 1910 by Captain Paul Berthon from the archaeological site of Pachacamac, the largest sanctuary on the central coast of Peru. These pieces have induced a strong reaction in the French scientific community, which has described them as "some vulgar fake" because of a particular decoration and also their unique typology. We will present also the dating of 2 Tibetan textiles and 2 pre-Columbian ponchos made with feathers, which were not well documented. The last example concerns a decorated skull covered with a mosaic of blue and black turquoises and belonging to a civilization predating the Aztecs (AD 1300-1500). All these examples illustrate the decisive contribution of ${ }^{14} \mathrm{C}$ dating to the authentication of museum objects that lack information about their origin.
\end{abstract}

\section{INTRODUCTION}

Since the 15th century, many French explorers have traveled around the world to discover new horizons and to extend France to new territories. From their long and hazardous trips, they brought back many pieces of material evidence used to support and confirm their view on the traditions and customs in these distant lands. All these objects were gathered in cabinets of curiosities and then in ethnographic museums. Among these sometimes very ancient collections, many objects, removed from their archaeological or historical context, have given rise to questions about their authenticity.

The authentication process of ethnographic objects requires a thorough knowledge and identification of constituent materials and fabrication techniques (Mazel et al. 2008), whose the ultimate step is the assignment to a culture in relation with a region. Of course, direct radiocarbon dating of these objects is a criterion of choice for a better assessment of their age, an essential data to place them in the time (Van Strydonck et al. 1992; Brock et al. 2012; Ostapkowicz et al. 2012).

In addition, these ethnological objects have a very complex past: ancient or not, daily or never used, more or less degraded with time; they have also a museal history, sometimes unknown or not documented. For example, many objects have been submitted to the addition of conservation or restoration products (varnishes, consolidants) or cleaning products on their surface, or simply to an excessive manipulation by a great number of people. Therefore, the pretreatment or cleaning steps of samples before ${ }^{14} \mathrm{C}$ measurement has to be undertaken with particular caution.

This paper describes the contribution of the ${ }^{14} \mathrm{C}$ dating method to a few significant examples of ethnographic objects coming from the collections of the Quai Branly Museum (Paris, France) and the Museum of African Arts (Marseilles, France). These examples illustrate the decisive contribution of ${ }^{14} \mathrm{C}$ dating to the knowledge of museum objects, with imprecise information about their origin.

${ }^{1}$ Corresponding author. Email: pascale.richardin@culture.gouv.fr.

(c) 2013 by the Arizona Board of Regents on behalf of the University of Arizona

Proceedings of the 21st International Radiocarbon Conference edited by A J T Jull \& C Hatté

RADIOCARBON, Vol 55, Nr 2-3, 2013, p 1810-1818 


\section{P Richardin \& N Gandolfo}

\section{EXPERIMENTAL}

\section{Sample Preparation}

In order to eliminate minerals, dust, or possible solid particles, samples have been washed with ultrapure water (Direct-Q system from Millipore). Then, organic constituents present from conservation or restoration treatments (varnishes or synthetic resins), frequently used in museum contexts, have been removed with a mixture of methanol/dichloromethane (1/1) and finally with acetone (AnalaR Normapur, from VWR International) in an ultrasonic bath. Before each treatment, samples were thoroughly rinsed 3 times with ultrapure water.

Vegetal samples have been treated with the well-established AAA method (Richardin et al. 2010a,b), with a $0.5 \mathrm{M} \mathrm{HCl}$ solution (from VWR International), followed by a $0.01 \mathrm{M} \mathrm{NaOH}$ aqueous solution (from VWR International), and once again with the $0.5 \mathrm{M} \mathrm{HCl}$ solution. Before each treatment, the supernatant is removed with a glass pipette and the remaining fragments rinsed with ultrapure water until neutrality of the washing waters. The protocol used for the preparation of feather samples is based on the selective extraction of keratin by reduction using dithiothreitol, followed by precipitation of the extract in the presence of sodium deoxycholate (DCO) and trichloroacetic acid (TCA). The method has been previously described in detail (Richardin et al. 2011).

For the preparation of bone samples, the Longin (1971) method was used, which involves extraction of the soluble collagen. At first, a large part of the mineral fraction (calcium phosphates and carbonates) is dissolved in cold hydrochloric acid. Samples are then submitted to a treatment with dilute sodium hydroxide, and a partial hydrolysis is carried out with hydrochloric acid to $\mathrm{pH} 3$ overnight. Finally, the cleaned samples are dried overnight in a low-vacuum $(100 \mathrm{mbar})$ oven at $60{ }^{\circ} \mathrm{C}$. The organic fraction has been then combusted at high temperature $\left(5 \mathrm{hr}\right.$ at $\left.850^{\circ} \mathrm{C}\right)$ under high vacuum (106 Torr), with $\mathrm{CuO}$ (for analysis, from VWR International) and a piece of silver wire (99.95\%, from Aldrich). The collected $\mathrm{CO}_{2}$ gas is transformed into graphite by catalytic reduction with hydrogen, using Fe powder at $600{ }^{\circ} \mathrm{C}$ and with an excess of $\mathrm{H}_{2}$. This last step is conducted in the laboratory of the LMC14, Gif-sur-Yvette Cedex, France.

\section{Radiocarbon Measurements and Calibration}

${ }^{14} \mathrm{C}$ measurements have been performed on the Artemis AMS (National Electrostatics Corp.) facility of Saclay, France (Cottereau et al. 2007) and the ${ }^{14} \mathrm{C}$ ages (in yr BP) are calculated after correction of the isotope fractionation $\delta^{13} \mathrm{C}$ measured by AMS. Calendar ages are determined using the CALIB rev 6.0.0 (Stuiver and Reimer 1993) or OxCal v 4.1 programs (Bronk Ramsey 2009) and the calibration curves IntCal09 (Reimer et al. 2009) or SHCal04 (McCormac et al. 2004). Calibrated age ranges correspond to $95.4 \%$ probability $(2 \sigma)$ and are expressed in years cal $\mathrm{BC}$ or cal AD.

\section{RESULTS}

The ${ }^{14} \mathrm{C}$ ages and the calibrated calendar time ranges of the samples are given in Table 1.

\section{War Bludgeon from Tupinambá Indians (Brazil), Quai Branly Museum (Paris, France)}

The Tupinambá are Brazilian native tribes, formerly known for their cannibalism. A main instrument used in ritual killing by this ethnic group was a bludgeon, called an ibirapema. The bludgeon studied was cut from a hardwood, is about 5 feet long with a rounded head, and is specially decorated for the occasion with colored feathers and vegetal fibers. It is reported that a similar bludgeon was acquired by Brother André Thévet (1515-1590), who offered it to the king for his cabinet of 


\section{${ }^{14} \mathrm{C}$ Dating and Authentication of Ethnographic Objects}

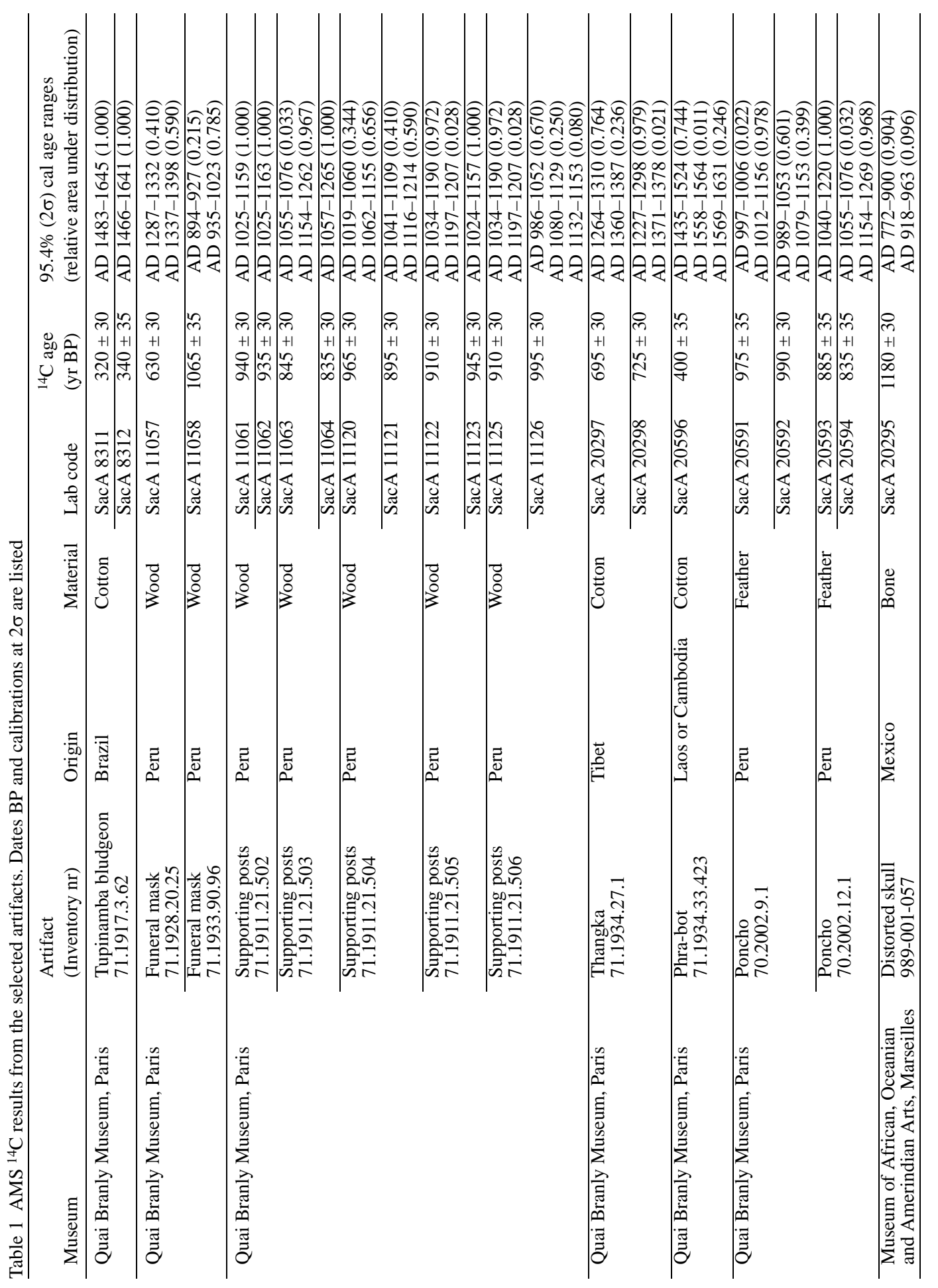




\section{P Richardin \& N Gandolfo}

curiosities (Métraux 1932). However, this author suggests that the bludgeon from the Quai Branly Museum, Paris, is likely not that of Thévet.

It is for this reason that a complete study was conducted by the C2RMF team (Lavier et al. 2009), and in particular the ${ }^{14} \mathrm{C}$ dating of the textile decoration was performed (Figure 1). Two samples of textile fibers, identified as cotton, were collected and prepared according to the classical AAA procedure. The calibrated dates (Richardin et al. 2010a) obtained for the 2 collected samples (Table 1) are in the range AD 1483-1645 and 1466-1641. The decoration of the bludgeon seems therefore to be contemporary to the expeditions of Andre Thévet, and thus, this object can be considered among the oldest pieces of American collections in France.

Figure 1 The Tupinambá bludgeon from the Quai Branly Museum (Inv. N. 71.1917.3.62) and the textile decoration (CC2RMF, Daniel Vigears).

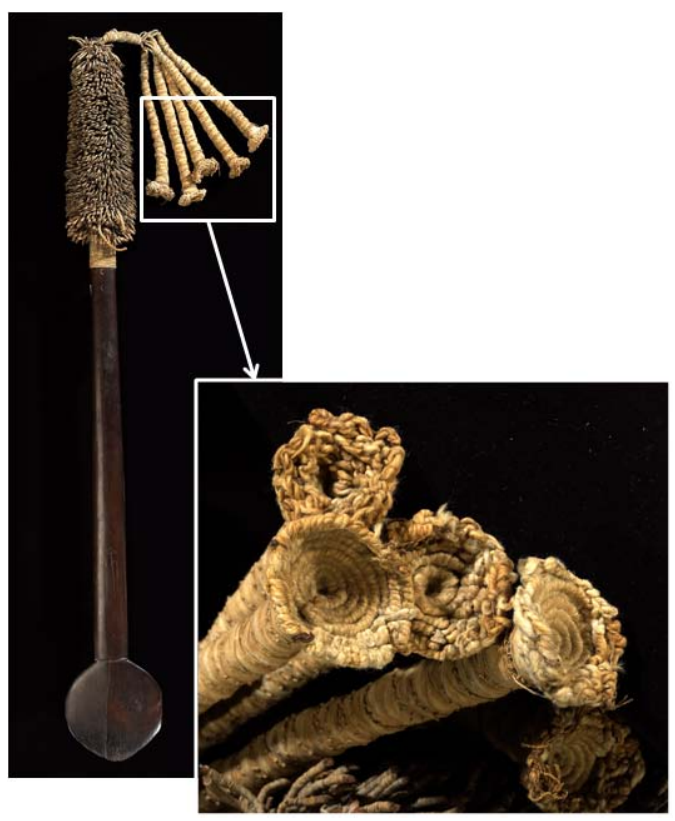

\section{Wooden Architectural Columns from Pachacamac (Peru), Quai Branly Museum (Paris, France)}

Five architectural columns or supporting posts, from the America section of the Quai Branly Museum in Paris, were given in 1910 by Captain Paul Berthon, who said that they were coming from the site of Pachacamac, the largest sanctuary of the coast of Peru. Their authenticity was questioned due to a surprising decoration and strong criticisms (Anonymous 1911a). Indeed, supporting posts of this type, considered to be idols because of their anthropomorphic form, are known on the southern coast of Peru, but they are smooth or have only a simple decoration on the top. Inlays of colored shells or stones are not common in this period and only appear later. Moreover, no specimens of this type have been found to date in Pachacamac. In 1911, a scientific committee was appointed to discuss the authenticity of these idols, and concluded (Anonymous 1911b) that they looked ancient and that nothing could suspect their authenticity, except for the red-painted one, Inv. N. 71.1911.21.506, which looked more recent. Thus, it seemed important to date these 5 objects, to verify or to confirm their authenticity, and especially to place them according to the archaeological chronology of the pre-Columbian periods.

A xylological analysis of 3 of these supporting posts has shown that they are made of lúcuma wood (Moutarde 2006). Pouteria lucuma is a tree of the Sapotaceae family originating from Peru. It is an 


\section{${ }^{14} \mathrm{C}$ Dating and Authentication of Ethnographic Objects}

evergreen tree, reaching 15 feet high and its wood is light colored, fine grained, and tough. The ${ }^{14} \mathrm{C}$ measurements of wood samples from the 5 objects have confirmed their authenticity. The calibrated dates (Figure 2) are fall between around AD 1000 and 1250, and we can attribute these pieces to the Late Intermediate period. This period covers the time that elapses between the fall of Huari Empire and the conquest by the Incas (Eeckhout 1997).

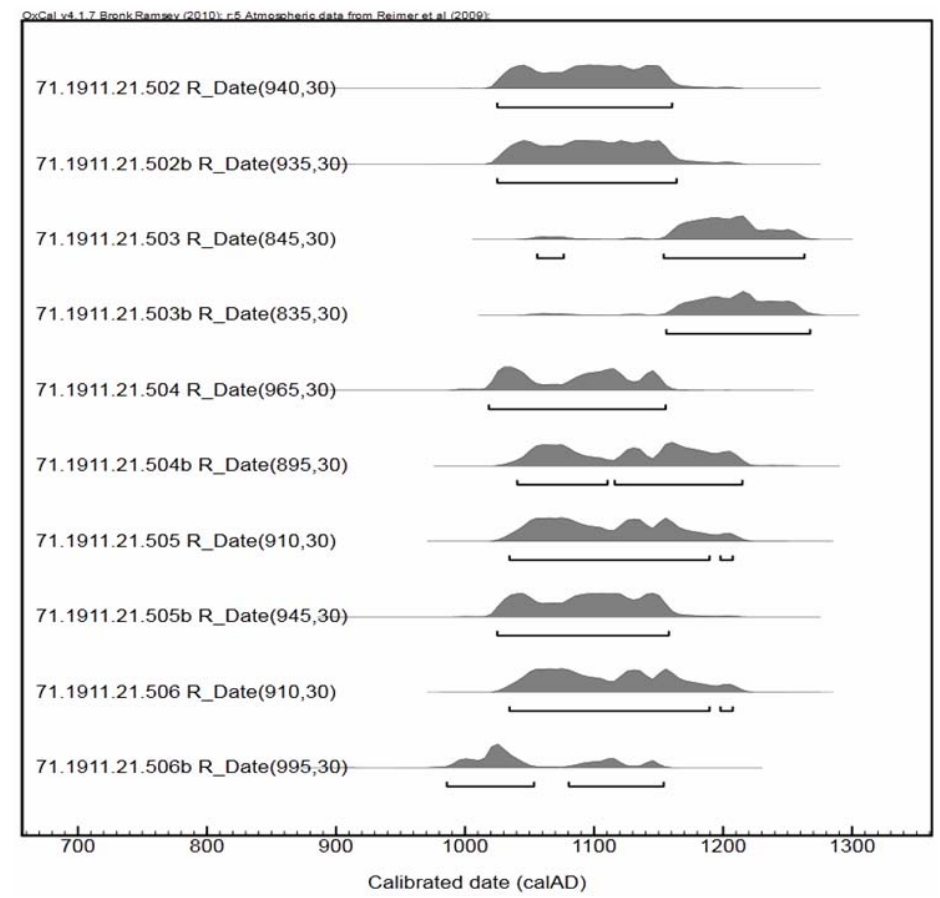

Figure 2 Multispot calibrated ${ }^{14} \mathrm{C}$ ages for the 5 supporting posts

We were interested in this study, to add to our corpus 2 other pieces from the site of Pachacamac: the 2 colored funerary masks 71.1928.20.25 and 71.1933.90.96, which have been given by the Americanist Raoul d'Harcourt and Mr Langlois, respectively. The results show that the masks are not contemporary, and the dates correspond to other phases of exploitation of the site.

\section{Deformed Skull with Mosaics (Mexico), MAAOA (Marseilles, France)}

A skull, covered with a blue and black mosaic (Figure 3a), from the collector and neurologist Henri Gastaut, now belongs to the Museum of African Arts, Oceanians, Amerindians (MAAOA, Marseilles, France). This famous deformed skull from Mexico has faced some adventures before entering the museum collections. However, the absence of archaeological information gives rise to numerous questions about its origin: is it an authentic object of pre-Hispanic times, or is it reconstructed in the 20th century from authentic elements, or even is it a complete counterfeit? Thus, a multidisciplinary study was undertaken on this skull, and ${ }^{14} \mathrm{C}$ dating was a decisive tool. We were allowed to take a piece of bone at the back of the skull (Figure 3b). ${ }^{14} \mathrm{C}$ dating of the small bone fragment (1180 $\pm 30 \mathrm{yr} \mathrm{BP}$ ) gave a date between AD 772 and 900 (Figure 3c). It therefore appears that the skull belongs to a civilization predating the Aztecs, possibly the Mixteco civilization (AD 900 to 1500 ). 


\section{P Richardin \& N Gandolfo}

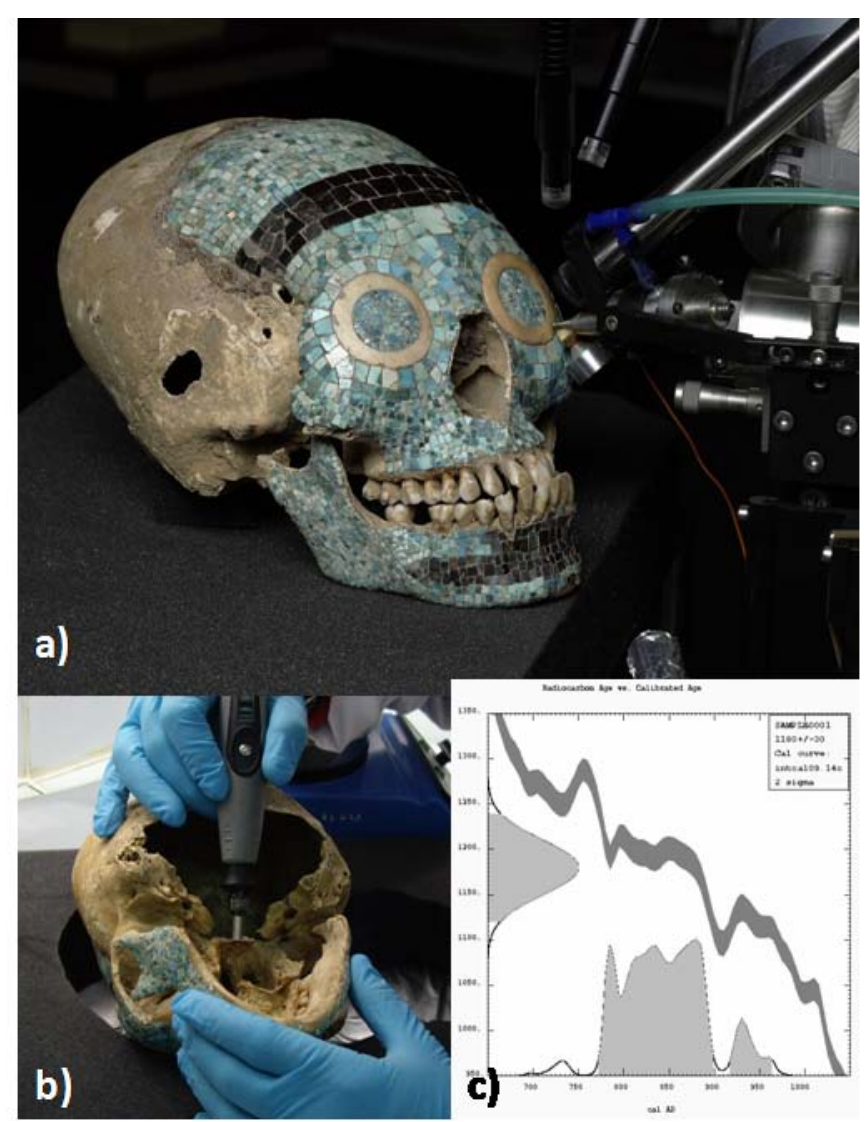

Figure 3 The deformed skull with mosaics (Mexico) from the MAAOA museum (a) under the beam of the AGLAE accelerator ( $\subseteq$ C2RMF, Thomas Calligaro), (b) collecting the bone sample (@ C2RMF, Nathalie Gandolfo), and (c) calibration of the ${ }^{14} \mathrm{C}$ date.

The skull, considering its deformations and its date, would be pre-Columbian, but the other materials give a more subtle picture. In particular, the glue used to stick the mosaics (shellac) is different from that identified in the 10 other pre-Columbian mosaics studied previously (Copal resin type). Shellac is indeed widely spread in Asia and Europe in this period, but its use in pre-Hispanic America, while not impossible, has never been reported. Thus, the authenticity of the skull has not been truly confirmed and further investigations should be undertaken, perhaps by ${ }^{14} \mathrm{C}$ dating the traces of glue (Calligaro et al. 2011).

\section{Two Asian Textiles, Quai Branly Museum (Paris, France)}

During the campaign of restoration of textiles from the Quai Branly Museum and in agreement with the curators of the museum, small samples were taken ${ }^{14} \mathrm{C}$ dating from 2 textiles of the Asian Department. The first textile is a Tibetan thangka (Inv. N. 71.1934.27.1). This Buddhist representation is painted on each side of the canvas and depicts the goddess dPal-ldan-lha-mo, considered the main Protectress of Tibet (Figure 4a). Such double-sided paintings are very rare and always predate the 17th century. We have taken a sample on the upper part of the canvas and have selected some detached fibers and without (apparently) traces of colored materials. After verifying the nature of 
the textile by infrared spectroscopy, the sample was prepared according to the AAA protocol. The 2 ${ }^{14} \mathrm{C}$ dates are $695 \pm 30$ and $725 \pm 30$ yr BP (duplicates from the same sample preparation), which correspond to calendar dates between AD 1264-1310 and 1227-1298.
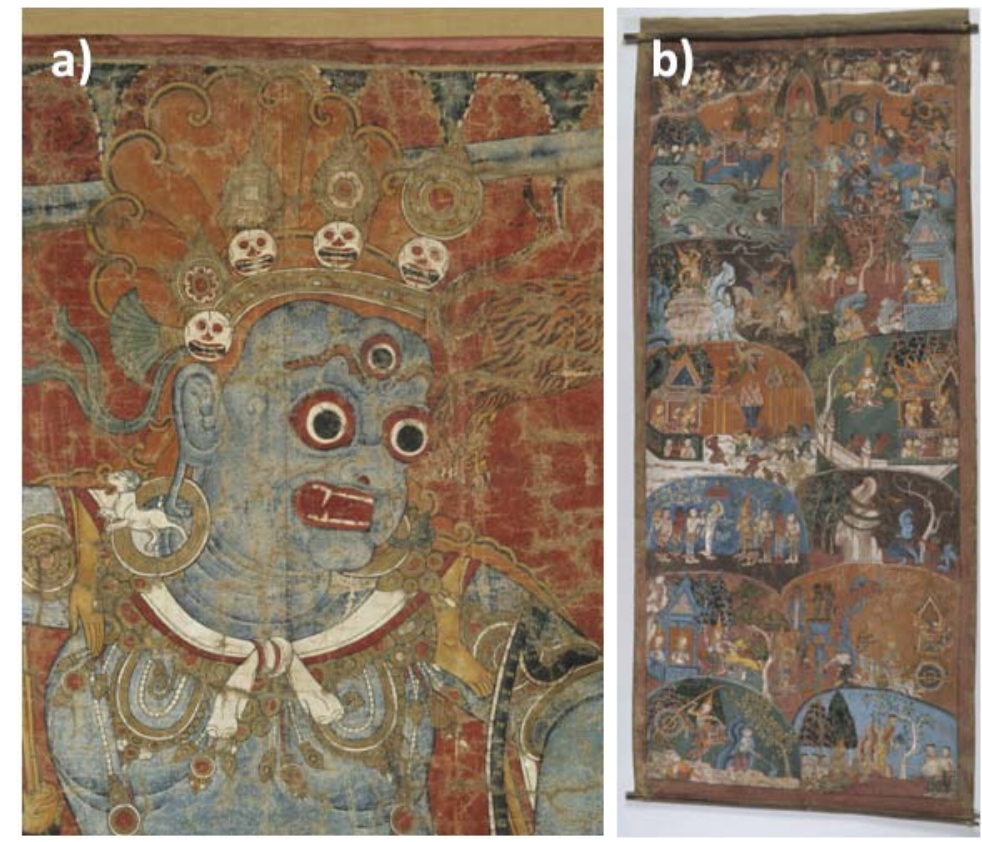

Figure 4 (a) Detail of the Tibetan thangka (Inv. N. 71.1934.27.1) and (b) the Southeast Asian “phra-bot” (Inv. N. 71.1934.33.423) (@C2RMF, Anne Chauvet).

The second textile is a "phra-bot" from Laos or Cambodia (Inv. N. 71.1934.33.423). This large banner of painted cotton (Figure $4 \mathrm{~b}$ ), depicting the life of Buddha, was thought to be from the 18th or 19th century (Bergeaud et al. 2006). A small piece of tissue was cut on the side of the painting, avoiding the painted areas, for dating.

The calibration of ${ }^{14} \mathrm{C}$ date obtained for the textile (400 $\pm 35 \mathrm{yr} \mathrm{BP}$ ) provides a calendar date between AD 1435 and 1524. Thus, we can estimate with a high probability that the object dates from the early 15th to the early 16th century. These results show that these sacred textiles are older than expected.

\section{Poncho with Feathers (Peru), Quai Branly Museum (Paris, France)}

The last example concerns a poncho (Inv. N. 70.2002.9.1) made with blue and yellow feathers assembled on a frame of cotton (Figure 5), originating from Peru and supposedly of the Wari Empire (AD 700-1100). During its restoration, a few feathers were detached from the support. Since a feather consists mainly of b-keratin, we decided to use the protocol that was developed to extract and reprecipitate materials based on keratin (Richardin et al. 2011). The $2{ }^{14} \mathrm{C}$ dates obtained on feathers ( $975 \pm 35$ and $990 \pm 35 \mathrm{yr}$ BP) give a calendar date between the 11th and mid-12th century $\mathrm{AD}$ and confirm the attributed civilization. 


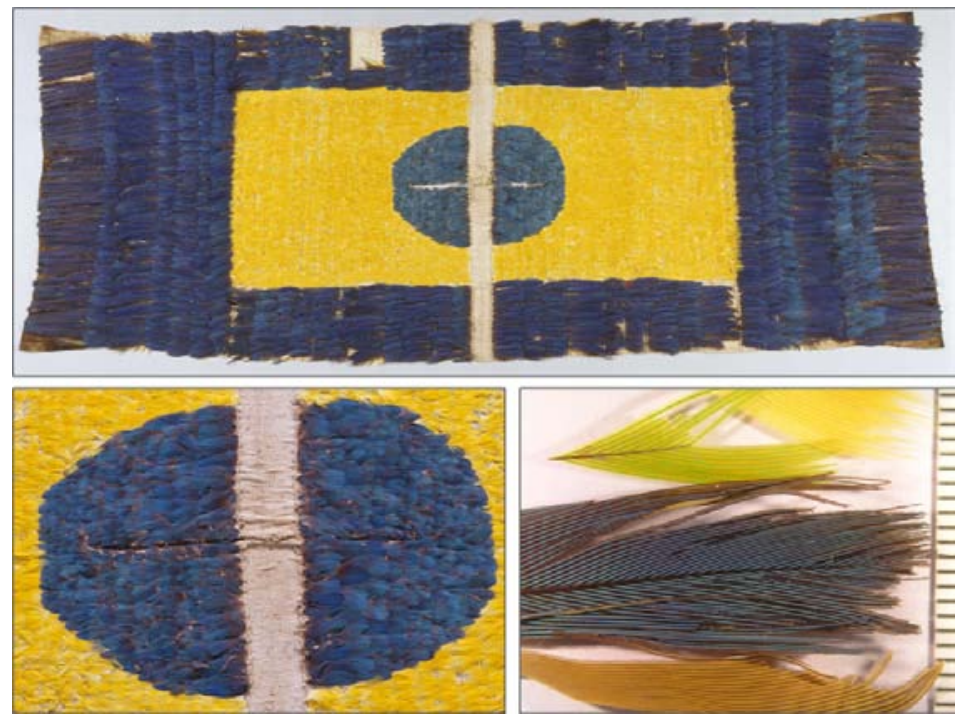

Figure 5 The poncho (Inv. N. 70.2002.9.1) (@C2RMF, Anne Chauvet, Nathalie Gandolfo)

\section{CONCLUSION}

With the few examples presented herein, we show the important contribution of ${ }^{14} \mathrm{C}$ dating applied to ethnological objects from museums. It helps to highlight these poorly understood and sometimes underestimated collections, by assessing the real authenticity of the objects. Very different materials can be dated, e.g. wood, bones, feathers, vegetal textiles (cotton, flax, etc.) or from animal origin (wool, silk). Therefore, sample preparation protocols have been established that have to be very specific and unique to each category. It is necessary to ensure, by complementary physico-chemical analysis (e.g. infrared spectroscopy), that no exogenous products remain that can affect the ${ }^{14} \mathrm{C}$ dating, especially varnishes, glues and other products of conservation-restoration, frequently used for museum collections.

\section{ACKNOWLEDGMENTS}

The authors are very grateful to Yves Lefur (director of the Heritage and Collections Department), André Delpuech (curator, in charge of the Patrimonial Unity of Americas), and Paz Núñez-Regueiro (curator, in charge of the American collections) for permission to sample the artifacts from the Quai Branly Museum. Thank you also to Marianne Pourtal Sourrieu (curator in the MAAOA Museum) for the possibility to take a sample from the skull with mosaic. We want also to thank Thomas Calligaro, physicist at the C2RMF, for the study of the Mexican skull and Catherine Lavier (dendrochronologist at the C2RMF and now at the University of Pierre et Marie Curie) for the wood sampling. The authors would like to thank Christophe Moreau and his team (LMC14, CEA Saclay, France) for the graphitization and the ${ }^{14} \mathrm{C}$ measurements.

\section{REFERENCES}

Anonymous. 1911a. Actes de la société. Journal de la Société des Américanistes 7:243-58.

Anonymous. 1911b. Actes de la société. Journal de la Société des Américanistes 8:271-82.

Bergeaud C, Forestier S, Sindaco Domas C, Cevoli D. 2006. Un thang-ka double face: restauration et muséographie. Technè 23:93-7.

Brock F, Ostapkowicz J, Bronk Ramsey C, Wiedenhorft AC, Cartwright C. 2012. Paired dating of pith and outer edge (terminus) samples from Prehispanic Caribbean wooden sculptures. Radiocarbon 54(3-4): 677-88. 


\section{${ }^{14} \mathrm{C}$ Dating and Authentication of Ethnographic Objects}

Bronk Ramsey C. 2009. Bayesian analysis of radiocarbon dates. Radiocarbon 51(1):337-60.

Calligaro T, Coquinot Y, Dumora C, Le Hô A-S, Langlois J, Gandolfo N, Richardin P. 2011. Etude scientifique: analyse et datation des matériaux. In: Xihuitl. Images en Manœuvres. p 24-37.

Cottereau E, Arnold M, Moreau C, Baqué D, Bavay D, Caffy I, Comby C, Dumoulin JP, Hain S, Perron M, Salomon J, Setti V. 2007. Artemis, the new ${ }^{14} \mathrm{C}$ AMS at LMC14 in Saclay, France. Radiocarbon 49(2):2919.

Eeckhout P. 1997. Pachacamac durant l'Intermédiaire récent. Étude d'un site monumental préhispanique de la Côte centrale du Pérou [PhD thesis]. Brussels: Free University.

Lavier C, Borel T, Vigears D. 2009. Traceology applied to wooden artefacts and works of art in French national museums: initial examples of adaptations, technical developments and results at C2RMF. Technè 29: 15-20.

Longin R. 1971. New method of collagen extraction for radiocarbon dating. Nature 230(5291):241-2.

Mazel V, Richardin P, Debois D, Touboul D, Cotte M, Brunelle A, Walter P, Laprévote O. 2008. The patinas of the Dogon-Tellem statuary: a new vision through physico-chemical analyses. Journal of Cultural Heritage 9(3):347-53.

McCormac FG, Hogg AG, Blackwell PG, Buck CE, Higham TFG, Reimer PJ. 2004. SHCal04 Southern Hemisphere calibration 0-11.0 cal kyr BP. Radiocarbon 46(3):1087-92.

Metraux A. 1932. A propos de deux objets Tupinambis. Bulletin du Musée d'Ethnographie du Trocadéro 3:18.

Moutarde F. 2006. L'évolution du couvert ligneux et son exploitation par l'homme dans la vallée du Lurín (côte centrale du Pérou), de l'Horizon Ancien (900-100 av. J.-C.) à l'Horizon Tardif (1460-1532 ap. J.-C.) [PhD thesis]. University of Paris 1, Archaeology and Envi- ronment. $509 \mathrm{p}$.

Ostapkowicz J, Bronk Ramsey C, Brock F, Higham T, Wiedenhoeft AC, Ribechini E, Lucejko JJ, Wilson S. 2012. Chronologies in wood and resin: AMS ${ }^{14} \mathrm{C}$ dating of pre-Hispanic Caribbean wood sculpture. Journal of Archaeological Science 39(7):2238-51.

Reimer PJ, Baillie MGL, Bard E, Bayliss A, Beck JW, Blackwell PG, Bronk Ramsey C, Buck CE, Burr GS, Edwards RL, Friedrich M, Grootes PM, Guilderson TP, Hajdas I, Heaton TJ, Hogg AG, Hughen KA, Kaiser KF, Kromer B, McCormac FG, Manning SW, Reimer RW, Richards DA, Southon JR, Talamo S, Turney CSM, van der Plicht J, Weyhenmeyer CE. 2009. IntCal09 and Marine09 radiocarbon age calibration curves, 0-50,000 years cal BP. Radiocarbon 51(4): 1111-50.

Richardin P, Gandolfo N, Moignard B, Lavier C, Moreau C, Cottereau E. 2010a. Centre of Research and Restoration of the Museums of France: AMS radiocarbon dates list 1. Radiocarbon 52(4):1689-700.

Richardin P, Cuisance F, Buisson N, Asensi-Amoros V, Lavier C. 2010b. AMS radiocarbon dating and scientific examination of high historical value manuscripts: application to two Chinese manuscripts from Dunhuang. Journal of Cultural Heritage 11(4):398-403.

Richardin P, Gandolfo N, Carminatti P, Walter P. 2011. A new protocol for radiocarbon dating of hair and keratin type samples - application to an Andean mummy from the National Museum of Natural History in Paris. Archaeological and Anthropological Sciences 3(4): 379-84.

Stuiver M, Reimer PJ. 1993. Extended ${ }^{14} \mathrm{C}$ data base and revised CALIB $3.0{ }^{14} \mathrm{C}$ age calibration program. $R a$ diocarbon 35(1):215-30.

Van Strydonck M, van der Borg K, de Jong A. 1992. Dating Precolumbian museum objects. Radiocarbon 34(3):928-33. 